\title{
An Empirical Estimation of the Underground Economy in Ghana
}

\author{
Edward Asiedu ${ }^{1}$ and Thanasis Stengos ${ }^{2}$ \\ ${ }^{1}$ Department of Economics, Georg-August Universität Göttingen, Heinrich-Düker-Weg 12, 37073 Göttingen, Germany \\ ${ }^{2}$ Department of Economics and Finance, University of Guelph, Guelph, ON, Canada N1G 2W1 \\ Correspondence should be addressed to Edward Asiedu; easiedu@gwdg.de
}

Received 29 April 2014; Accepted 9 June 2014; Published 21 July 2014

Academic Editor: Vicente Esteve

Copyright (c) 2014 E. Asiedu and T. Stengos. This is an open access article distributed under the Creative Commons Attribution License, which permits unrestricted use, distribution, and reproduction in any medium, provided the original work is properly cited.

\begin{abstract}
The main aim of this paper is to estimate the size of the underground economy in Ghana during the period 1983-2003. There is no agreement on the appropriate estimation approach to adopt to measure the size of the underground activities. To this end, we employ the well-applied currency demand approach in our measurement. Parameter estimates from the estimated currency demand equation are used in quantifying the ratio of "underground" to "measured" output/income for the Ghanaian economy. The estimated long-run average size of the underground economy to GDP for Ghana over the period is $40 \%$. The underground economy is found to vary from a high of $54 \%$ in 1985 to a low of $25 \%$ in 1999. Estimates may represent lower bound estimates.
\end{abstract}

\section{Introduction}

Ghana sticks out as a country with a moderate but persistent economic growth and successes in poverty reduction over the last decade. The country is home to a population of about 24 million people, with more than 100 different ethnic groups [1]. Out of this population, Ghana's labor force in 2008 totalled about 11.5 million people. The economy continues to rely heavily on agriculture which accounts for $37.3 \%$ of GDP and provides employment for $56 \%$ of the work force in 2007. Manufacturing is only a small part of the Ghanaian economy totalling $7.9 \%$ of GDP in 2007. Based on current statistics [1], Ghana is doing politically and economically well compared to other developing.

In terms of politics, Ghana happens to be the first sub-Saharan African country to gain independence in 1957. Despite this success, the country had seen a series of political unrest from 1966 to 1981 leading to serious economic decline over the period. Political unrest coupled with famine in the early 1980s leads to a broken economic system inter alia: high inflation, huge depreciation of the country's currency (cedi), high unemployment, and huge budget deficits (see [2]). The incidence of huge budget deficits over the period is attributed in part to low revenue mobilization and the strong affinity for people to take advantage of the broken system by avoiding paying of their fair share of taxes. The high inflation (e.g., about $122 \%$ in 1983) over the period served as a further incentive for people to indulge in underground activities in order to be able to provide the basic needs for their households. All these activities led to the intervention by the IMF and subsequently led the country on the path of structural adjustment. Economic reforms were subsequently implemented in 1983. The focus of this study is on the size of the underground activities in Ghana over the period 19832003.

The size of a country's national wealth is pivotal in the national development agenda of the country. Specifically, the sustainability and the existence of strong economies to a great extent depend on the generation of a sizeable proportion of the economy's developmental resources domestically. Developed countries rely largely on their national incomes for the provision of a wide range of social services such as the provision of roads, infrastructure, quality education, hospitals, recreational centers, and all other social services. However, the opposite does exist in the developing world. In most of the developing countries, annual budget deficits have been observed as a chronic problem. And as such, most of the developing countries finance their expenditure through huge borrowings from the developed OECD countries or from international institutions such as the World Bank and 
IMF. In some instances, foreign aid from the developed to the developing countries does help to lessen the financial strain emanating from the existence of significant budgetary deficits, as well as mitigate the high interest rate on borrowings. The role of domestically generated funds in ensuring a healthy economy can therefore not be overemphasized.

Even though developing countries have a relatively lower capacity to generate income, in many instances and for many countries in the bracket, a significant proportion of the national income goes unreported or uncaptured as measured GDP (see [3]). In fact the recorded output for most countries actually understates the actual output of the economy, with developing countries perceived to have a relatively higher unrecorded hidden economy. One of the objectives of most of the developing countries including Ghana is to increase domestic revenue mobilization and widen the tax net. However, this objective stands to be defeated, if the underground economy forms a larger and persistently increasing proportion of the total economy. Aside from the differences in the size of the unrecorded hidden economy across countries and regions, they do also vary over the business cycle $[4,5]$.

Research into underground economies in recent times has gained prominence in the literature. There have been a number of reasons attributed to the increase in research into this area of study. Giles $[4,5]$ observed that the rise in research into this area of study is due to the growing problem of foregone revenue resulting from the underground economy. Underestimating the GDP implies, for example, an overestimation of the public deficit/GDP and Debt/GDP ratios; therefore, any fiscal and monetary policy decision would be based on biased official figures [6]. Hill [7] identified the political implication of having a much higher proportion of an economy's income being unreported as one possible reason for the increasing interest in the area. Thus, the economic and political implication of having a bigger size of the total economy hidden are enormous for most of the countries including Ghana.

However, even though this area of research has intrigued researchers in recent times, there has not been a unifying agreement on the terminologies used to describe the unrecorded portion of the total economy, as well as the method of estimation of the size of the unrecorded economy. The terminologies used in the literature include black economy, informal economy, second economy, unofficial economy, hidden economy, underground economy, shadow economy, and irregular economy (see $[6,8-13])$. In terms of methods, the most prominent of methods used in estimating the size of the underground economy includes voluntary survey and sampling, tax auditing, discrepancies between official and actual labour force, physical input (electricity consumption), monetary approach, and the latent indicator approach. Approaches used under the monetary method include the currency ratio approach, transaction approach, and the currency demand approach. This paper relies on the currency demand approach to measure the size of the underground economy. The goal of this paper is to quantify the size of the underground economy in Ghana and also describe the time profile for the underground economy for the period, 1983-2003. To the best of our knowledge there has been no research which focuses solely on obtaining measures of Ghana's underground economy using a currency demand model.

\section{Literature Review}

2.1. Definition of Underground Economy. Underground economy estimation has gain prominence in the literature and so is the debate relating to the appropriate definition and estimation approaches. Researchers have not been able to settle on a unified definition and methodology for estimating the underground economy. The reason for the disagreement is that the underground economy is not directly observable (hidden). As such trying to measure a hidden phenomenon raises a number of issues.

Schneider [14] defined the underground economy activities as all economic activities that contribute to value added and should be included in national income in terms of national accounting conventions but are presently not registered by national measurement agencies. Smith [15] defines it as market based production of goods and services, whether legal or illegal, that escapes detection in the official estimates of gross domestic product. Tanzi and Schuknecht [9] broadly defined underground economy as the economic activities that are hidden from public authorities to avoid taxation. However, the definition of the underground economy by Tanzi and Schuknecht [9] is a bit narrow in the sense that it assumes tax evasion to be the only motivation for the existence of the underground economy. The underground economy activities can be categorized into the legal economic activities, the illegal economic activities, and the nonmarket economic activities [16].

The legal hidden economic activities basically refer to economic activities that are carried out in contradiction to existing tax laws, either intentionally or due to inefficiencies on the part of the revenue institutions. Such activities include businesses that overstate their expenses, legitimate income earned and laundered abroad, incomes concealed or under reported [3]. The illegal component deals with all economic activities that are prohibited by law such as the production and distribution of controlled substances (cocaine, marijuana, heroin, etc.), prostitution (in some countries), production and sales of restricted weaponry, contraventions of copyright laws, and labor provided by underage children.

Home production, bartering of services, and babysitting are some examples of nonmarket underground economic activities. The examples listed above as activities in the underground market do vary from country to country due to the differential capacity of the revenue institutions across countries. Developed countries have been observed to have a smaller nonmarket underground activity compared to developing countries. For example, revenue from activities such as prostitution and babysitting which are not captured in many developing countries is captured by the revenue agencies of a number of developed countries. Thus, the existence of underground markets is not sorely due to the motive of avoiding taxation as indicated by Tanzi and Schuknecht [9]. 
TABLE 1: Taxonomy of types of underground economic activities.

\begin{tabular}{|c|c|c|c|c|}
\hline Type of activity & \multicolumn{2}{|c|}{ Monetary transactions } & \multicolumn{2}{|c|}{ Nonmonetary transactions } \\
\hline \multirow[t]{2}{*}{ Illegal activities } & \multicolumn{2}{|c|}{$\begin{array}{l}\text { Trade with stolen goods, drug dealing and } \\
\text { manufacturing, prostitution, gambling, smuggling, } \\
\text { fraud, and so forth. }\end{array}$} & \multicolumn{2}{|c|}{$\begin{array}{l}\text { Barter of drugs, stolen goods, smuggling, and so } \\
\text { forth. Produce or growing drugs for own use. } \\
\text { Theft for own use. }\end{array}$} \\
\hline & Tax evasion & Tax avoidance & Tax evasion & Tax avoidance \\
\hline Legal activities & $\begin{array}{l}\text { Unreported income from } \\
\text { self-employment; wages, } \\
\text { salaries, and assets from } \\
\text { unreported work related to } \\
\text { legal services and goods }\end{array}$ & $\begin{array}{l}\text { Employee discounts, } \\
\text { fringe benefits }\end{array}$ & $\begin{array}{l}\text { Barter of legal services } \\
\text { and goods }\end{array}$ & $\begin{array}{l}\text { All do-it-yourself work } \\
\text { and neighbor help }\end{array}$ \\
\hline
\end{tabular}

Source: taken from Schneider, 2006 [16].

Table 1 presents the taxonomy of the types of underground economic activities.

Another source of disagreement in this field of research is not only in terms of the definition, but also in the acceptable terminology to use. A number of terminologies have been used in the literature to describe this phenomenon. Bagachwa and Naho [12] for instance referred to the underground economy as a second economy. In their paper, they distinguished between informal sector, parallel, and black market activities. The term informal sector is used to refer to very small-scale firms consisting of both employed workers and independent self-employed persons in both rural and urban areas. Bagachwa and Naho [12] argued that such firms are informal in the sense that they are for the most part unregistered, unrecorded in official statistics; and participants have little or no access to organized markets, to credit institutions, to formal education and training, or to many public services.

For parallel economy, Lindauer [17] referred to parallel activities as economic activities that involve illegal production and trade of goods and services that are legal in themselves and therefore have an alternative legal market. Such activities usually develop in response to excessive government interventions and restrictions which create excess demand or supply in a particular product or factor market. Bevan et al. [18] referred to black economy activities as all market activities that produce and/or distribute both market and nonmarket goods that are illegal and strictly forbidden by government statutes. Depending on which terminology a researcher adopts gives an indication of the component of the underground economy activity that the researcher intends to measure. Thus, care must be taken in some instance when using the numerous terminologies interchangeably.

It is therefore apparent that due to the complexity of the underground economy activities, many estimates of the underground economy activities from the literature may likely be lower bound estimates. On the definition of underground economy, the commonly used working definition of the underground economy in the literature is all currently unregistered economic activities that contribute to the officially calculated gross domestic products. This definition brings researchers a step closer to dealing with the disagreement associated with this issue. The focus of this study as indicated earlier deals with the unrecorded legal economic activity.
2.2. Causes of the Underground Economy. There are numerous reasons attributed to as the cause of an underground economic situation in various countries. The increase of tax burden and social security contributions has been observed in the literature as one of the most important reasons influencing the size of the underground economic activities. Gutmann [19] observed that high taxes and government regulation are the main causes of the existence of an underground economy. Yin's [20] observed that the existence of underground economy activities in China is due to the characteristics of evading tax, labor market supervision, and other factors relating to market friction. As it is known, taxes affect labor-leisure choices of economic agents and also encourage labor supply towards underground or untaxed sector of economy [21]. Higher tax and social security contributions can lead to lower tax income for employers and so it can create an incentive for employers to work in underground economy by employing workers from the underground economy, in order to reduce their cost of production. Schneider [16] indicated that the bigger the difference between the total cost of labor in the official economy and the after-tax earnings (from work), the greater the incentive to avoid this difference and to work in the shadow economy.

Perception of fairness and justice, in the tax system, does affect the incidence, as well as the size of the underground economies. All working adults of a population are expected to pay their due of taxes. When people perceive their neighbors as not paying their full due of taxes, it serves as an incentive for them not to pay too. Tyler et al. [22] study on tax compliance observed that even if paying tax means less money in a person's pocket, there is a perception of fairness knowing that everyone else who earns income is also paying their share of taxes. From the aforementioned studies, it shows the important role that tax incentives play influencing the size of the underground economy.

The role of institution in influencing the size of the underground economy cannot be overemphasized. Becker [23] indicated that the probability of detection and the size of the fine imposed determines the amount of income evaded. On the basis of weak institutions, a purely economic analysis of the evasion gamble implies that most individuals would evade if they are "rational," because it is unlikely that cheaters will be caught and penalized by the institutions of the system (see [24]). However, consistent enforcement of appropriate 
sanctions for those who do not pay their rightful taxes is an indication that the tax and law enforcement authorities are trustworthy, neutral, and respectful (see [22]). In some instances especially in the developing world, apathy towards tax payment arises in some cases due to the inability of institutions and governments in providing social services. People simply do not want to honour their tax obligation sorely because they think the government does "nothing" for them. Some studies found the lower capacity of revenue agencies to capture incomes from economic activities, which is an indication of weak economic institutions, contributing to the size of the underground economy (see $[25,26])$.

The increase in the intensity of regulations (often measured in the numbers of laws and regulations, like licenses requirements) is another important factor, which reduces the freedom (of choice) for individuals engaged in the official economy [16]. Such regulations may include market regulation, trade barriers, and labour restrictions especially for foreign workers and students. Johnson et al. [27] predict that countries with more general regulation of their economies tend to have a higher share of the unofficial economy in total GDP. Specifically, they found that a one-point increase of the regulation index (ranging from 1 to 5 , with $5=$ the most regulation in a country), ceteris paribus, is associated with a $10 \%$ increase in the shadow economy for 76 developing, transition, and developed countries.

High level of corruption further drives legal or potentially legal economic activities into underground. For instance, in situations where entrepreneurs are required to purchase a license from a corrupt official, in order to open a business in the official economy, the level of corruption and bureaucracy can push more legitimate or potentially legitimate businesses into underground, thereby leading to an increase in the size of the underground economy. Thus, going underground is seen as a substitute for bribery, although sometimes firms bribe officials in order to avoid official taxes (see [28]). Choi and Thum [29] showed that the entrepreneurs' option to flee to the underground sector constrains the corrupt official's ability to introduce distortion to the economy for private gains. Friedman et al. [30] showed that bureaucracy and underground economy are positively related. Table 2 summarizes the percentage of empirical study's findings on what the motivation for entering the underground economy is.

2.3. Consequences of the Underground Economy. The incidence, as well as the size of the underground economy, has dire economic and political consequences on a nation. Schneider and Enste [31] indicated that the growth of the underground economy can set off a destructive cycle. Declining taxation revenue is one of such consequences if there is an increased in untaxed transactions in the underground economy. Bajada and Schneider [3] indicated that whenever participation in the underground economy expands, tax revenue losses add to the financial pressures of governments to satisfy the service needs of the community. With reduced revenue, there is the tendency for governments to either reduce expenditure or increase taxes in order to provide the needed social services. Cater [32] indicated that doing so may drive more individuals into the underground economy or encourage existing underground participants to work more extensively. In the Canadian case, Perry's [33] study shows that a 15 percent underground economy means $\$ 28.6$ billion in foregone revenue: $\$ 15.8$ billion at the federal level, $\$ 11.5$ billion at the provincial level, and $\$ 1.3$ billion for the Canada pension plans. Giles $[4,5]$ estimates suggest that the New Zealand economy is losing between 6.4 percent and 10.2 percent of total tax liability from the underground economy. In the case of the U.S, Shelak [34] reported that the federal government was short an estimated $\$ 52$ billion in 1987 due to underground activities, which is 10.9 percent of the $\$ 476.5$ billion realized through the federal collection of individual and corporation net income taxes. In addition, tobacco product taxes in 1990 amounted to $\$ 5.5$ billion, the same year that approximately $\$ 200$ million of unreported income was earned by tobacco smugglers [34]. Thus, the presence of large underground economy undermines revenue collection, while increasing the cost of providing public services [35].

Individuals and businesses that participate in the underground economy not only contribute to lowering tax revenue collections but also bias economic and social information which policy makers use to gauge their economic policies (see [3]). If data are deficient because of the existence and growth of an underground economy, then we may have erroneous ideas about economic trends in employment, output, productivity, and inflation [36]. For example Feige [37] and Gutmann [19] have all argued that the unemployment rate in the U.S, as measured, is too high, due to the disregard of the existence of a large underground economy. Bajada and Schneider [3] indicated that the fact that unemployment may be consistently upward biased because of the underground economy may result in policies that are too expansionary and generate inflationary pressures. This is because expansionary or contractionary economic policies undertaken by the state to prevent an undesired economic condition may not take into consideration the underground sector (see [34]).

Feige [37] and Jeffrey [38] infer that prices are 20-40 percent lower underground in the U.S economy. The reasons being that most underground transactions untaxed and current marginal tax rates are roughly in the $20-40$ percent range for relevant underground suppliers. Consequently, they feel that sellers would be willing to pass along about that much advantage to buyers. If a business subcontracts labour from the underground economy at significantly lower costs, the firm is in a better position to price compete with its competitors, who may not be participating in the underground economy [3]. Legitimate businesses maybe be forced out of the market or maybe be compelled to also go underground if active underground activities blossom. The underground economy therefore promotes unfair price competition in both input and output markets.

The competitive advantage that the underground economy offers without doubt contributes considerably to efficiency and productivity losses (see [39]). Lemieux et al. [40] observed that underground-sector hours are negatively correlated with regular hours $(-0.156)$, regular wages $(-0.231)$, and regular earnings $(-0.185)$. However, with the 
TABLE 2: Main causes of the increase of the shadow economy.

Factors influencing the shadow economy

The most important driving forces are

Influence on the shadow economy (in $\%)^{1}$

(1) Increase of the tax and social Security contribution burdens

$35-38 \% \quad 45-52 \%$

(2) Intensity of state regulations

$8-10 \% \quad 10-15 \%$

(3) Social transfers

$5-7 \% \quad 5-8 \%$

(4) Specific labor market regulations

$5-7 \%$

$5-8 \%$

(5) Public sector services

$5-7 \%$

$5-8 \%$

(6) Tax morale ${ }^{2}$

$22-25 \%$

-

Overall influence

$76-94 \%$

${ }^{1}$ Average values of empirical results of 28 studies.

${ }^{2}$ Average values of "only" 15 studies.

Source: Schneider, 2006 [16].

underground economy having a competitive edge, resource therefore flows from the legitimate economy into the underground economy implying significant welfare losses. The underground economy is observed to distort the allocation of economic resources particularly if it is channeled into sectors of the economy where tax evasion is more pronounced [3]. By its very existence, the underground economy has a further impact on state finances on the expenditure side, affecting the level spent on law enforcement, drug rehabilitation, and prisons. As a result, funding is reduced or diverted from education, transportation, housing, and other socially positive governmental functions [34]. In addition, Bajada and Schneider [3] indicated that if there are a large number of individuals who are participating in the underground economy and not paying their fair share of tax, yet continue to expect the provision of public goods and services, they impose on honest tax payers the burden of raising the finances for their provision.

Paglin [41] observed that the large numbers of the poor, those whose declared incomes are low (or zero) and whose expenditures are substantial, have as their income source the underground economy. The incidence of the underground economy, and for that matter underreporting of incomes, makes it difficult to get a clear picture of the poverty population. People could in fact work in the underground economy and claim to be unemployed in order to receive welfare assistance. Bajada and Schneider [3] observed that, in such a case, combined income from both underground economy and welfare assistance could in most cases exceed the wage receive for similar (low paid) work in legitimate economy. Thus, income distortional inefficiencies are such a strong consequence of the incidence of underground economy. Rosser et al. [42] have also found a positive relationship between income inequality and the size of underground economy. However, the supposed relationship is somewhat disputable, since income inequality is mainly measured using "regular" incomes and this fact could lead to some bias [43].

Aside from the consequences of having a persistently increasing underground economy, other researchers have argued about some potential benefits that may accrue to the existence of an underground economy. Schneider and Enste [31] observed that two thirds of the income earned in the underground economy is immediately spent in the official economy. This can be a boost for the official economy and may lead to additional overall economic growth. Smith [15] suggests that since government regulations (such as minimum wages) as well as taxation are avoided, making the underground sector more flexible and better able to respond to rapidly changing market conditions than may be true for the regular economy. To buttress the aforementioned benefit of flexibility of the underground economy, Portes et al. [44] further suggested that the underground economy may adapt faster to changes in economic conditions thereby helping to accelerate structural changes necessary for economic development. It has also been suggested that lower prices for goods and services in the underground economy may also have some positive distributional effects when they help those on low incomes (see $[15,45])$. Reyneri [46] and Prager [47] suggested that some jobs only exist solely because they are inside the underground economy, because their full cost (i.e., including social contributions and income tax) would be too expensive to balance off their consistently low productivity. However, Carter [32] indicated that this may only be true of less developed economies that may have deficient planning for reallocating resources. On the basis of competition, Harding and Jenkins [48] argue that not only does the underground economy foster competition, but also reduces pressure on wages, stimulating economic growth while keeping inflation low.

Due to the renewed interest on the issue of underground economy, numerous attempts have been made in recent times to estimate the size of the underground economy in various jurisdictions. Table 3 presents the estimated size of the underground economy for different country groups as quantified by Schneider and Enste [31]. Developing countries are observed to have a relatively higher size of underground economy, followed by transition economies and then the OECD countries as showed in Table 3.

According to Schneider and Enste [31], Nigeria and Egypt had the largest underground economies, equivalent to $77 \%$ and 69\% of GDP, respectively, for the period 1998-1999; South Africa, by contrast, had an underground economy of about 11 percent of GDP. Schneider and Enste [31] further found that, in Asia in the same period, Thailand ranked number one 
TABLE 3: Underground economy as percent of official GDP, 19882000.

\begin{tabular}{lc}
\hline Country group & Percent of GDP \\
\hline Developing & $35-44$ \\
Transition & $21-30$ \\
OECD & $14-16$
\end{tabular}

Source: Schneider and Enste, 2002 [31].

with an underground economy of 70 percent of GDP; Hong Kong SAR and Singapore had the smallest underground economies, both at 14 percent of GDP. In Latin America in 1998-99, the biggest underground economy was in Bolivia, at 67 percent of GDP, and the smallest was in Chile, at 19 percent.

Schneider and Bajada [3] on their part did estimate the size of the underground economy for specific regions of the world. They found that the size of the underground economy over the period from 2000 to 2003 was larger for Africa and Central and South America as shown in Table 4. The underground economy in these two regions approximates over $40 \%$ of GDP for the period of the study. This is followed by East and Central Europe, with an underground economy averaging a little under $40 \%$ of GDP over the period of their study. The average size of the underground economy over the period 2002/2003 is 30.4\% of GDP for Asia and the Middle East, 16.3\% of GDP for the highly developed OECD, 33.4\% of GDP for the South Pacific Island countries, and 22.3\% of GDP for communist countries. The weighted average for the underground economy for 145 countries used in their study is approximately $34 \%$ of GDP.

Albu's [49] study on the underground economy in Romania suggested that the underground economy for the period 2000-2001 averages 20-21\% of GDP but 18\% in 1997. Giles et al. [50] suggest that the Canadian underground economy grew from about 3.5\% of measured GDP in 1976 to almost 16\% in 1995. However for the same Canadian economy Schneider [51] estimates show that it averaged $14.8 \%$ in $1994 / 95$ and $16.2 \%$ in 1997/98. Paglin's [41] study on the U.S underground economy indicates that the underground economy is declining slightly relative to the GDP. The underground economy activities as evident from this study declined from $10.2 \%$ in 1984 to $8.1 \%$ in 1992 . The study suggested that the observed decline may be related to the growth in jobs and employment in the 1980's. It must be mentioned that different approaches were adopt in the estimation of the underground economy by various researchers. From the literature, it is obvious that the different approaches yield different results. The next section of this paper presents the various approaches used in the literature in estimating the size of the underground economy.

\section{Methodology}

It is well known that undertaking attempts to measure the size of a hidden phenomenon is a difficult and challenging task. There have been a number of approaches that researchers over time have adopted to measure the size of the underground
TABLE 4: Average size of the underground economy.

\begin{tabular}{lcc}
\hline Regions & $2000 / 2001$ & $2002 / 2003$ \\
\hline Africa & 42.3 & 43.2 \\
Central and South America & 42.2 & 43.4 \\
Asia and Middle East & 29.5 & 30.4 \\
East and Central Europe & 39.1 & 40.1 \\
Highly developed OECD & 16.7 & 16.3 \\
South Pacific islands & 32.6 & 33.4 \\
Communist countries & 21.1 & 22.3 \\
Unweighted average-145 & 34.5 & 35.2 \\
countries & &
\end{tabular}

Source: Schneider and Bajada, 2005 [3].

economy. In this section our primary objective is to discuss the various estimation approaches and their associated lapses.

3.1. Direct Approach. The voluntary survey and the tax auditing methods constitute examples of the direct approach. The voluntary survey method estimates the size of the underground economy using survey data. Thus, individuals in the economy are interviewed to find out their involvement in the hidden economy. The questions typically deal with soliciting information about respondents' role in the underground economy either as a buyer or as a seller (see [3]). Schneider and Bajada [3] indicate doubt over the potential of this technique to uncover most of the underground activities taking place at any one time. Also, due to the sensitive nature of the topic and legal implications, there is a problem of willingness to cooperate and the truthfulness of their response. Thus, responses may be significantly bias [52].

For the tax auditing approach, the method estimates the size of underground economy from audit measurements of undeclared taxable income. The method is more important in identifying overestimation of deductible expenses rather than underreporting of income because expenses require receipts and concealed earnings need to be proven (see OECD). In practice, the underground economy is estimated by comparing income declared for tax purpose and income measured by selective checks, in order to find the amount of undeclared taxable income. The shortfall of this method is that only a small part of the underground economy is estimated by this method (see [3]).

3.2. Indirect Approaches. The national income accounting statistics approach is one example of an indirect method. It is seen as a "residual" approach ([3]). The analysis of difference between the legitimate income and expenditure is used as a proxy to measure the size of the underground economy activities (see $[3,8,53-55]$ ).

The transaction is another example of an indirect approach based on Fisher's quantity theory or $M V=P T$ (where $M=$ money, $V=$ velocity, $P=$ prices, and $T=$ total transaction). This method uses data on the overall volume of monetary transactions in the economy to calculate total nominal (unofficial plus official) GDP and then estimates size 
of underground economy by subtracting official GDP from total nominal GDP. The approach assumes first and foremost that there is a constant relation over time between the volume of transaction and official GNP. Secondly, assumptions are also made about the velocity of money and about the relationship between the value of total transactions $(P T)$ and total (official and unofficial) GNP. The approach further assumes that all variations in the ratio between the total value of transaction and the officially measured GDP are due to the underground economy. Bhattacharyya [56] indicated the unrealistic nature of such assumptions which further opens the method to criticisms.

The physical input approach is one other example of an indirect approach. It assumes electricity consumption as the single best indicator of overall economic activity (see [57]). Based on this approach, any growth of total electricity consumption is an indicator for growth of overall (official and unofficial). Lackó [58] assumes that, in each country, a part of the household consumption of electricity is used in the underground economy and further suggests that, in countries where the portion of the underground economy associated with the household electricity consumption is high, the rest of the underground economy is high. The use of the physical input approach has been criticized for a number of reasons. Firstly, not all underground economy activities require the use of electricity. Also, other sources of energy such as gas, oil, coal, and firewood, could be used in the underground economy, especially in developing countries where the informal sector forms a bulk of the underground economy.

The multiple indicators latent variable modeling procedure has been applied also to measure the size underground economy. Empirically, the method is complex using multiple causes and multiple indicators. This more complex approach is also known as the "structural equation model" or the "multiple indicator multiple cause" (MIMIC) (for complete and detail explanation of the MIMIC approach, see Frey and Weck-Hanneman [59], Dennis, et al. [60], Giles [4, 5], and Giles et al. [50]) model. This approach has been criticized for its inability to produce estimates that can be interpreted. In its application, it requires a benchmark estimate derived from alternative methodologies, which in most cases relies on the currency demand model which we employ in this paper (see $[4,5])$. In addition Giles et al. [50] observed that some causes and indicators may in fact be driving or driven by other economic phenomena, and as such there is no assurance that the estimates produced by the MIMIC model will reflect exact participation in the underground economy. The interaction between causal variables, indicator variables, and the unobserved phenomenon (underground economy) could be shown by Figure 1 .

Causal variables include the burden of direct and indirect taxation, both actual and perceived, and the burden of regulation as a proxy for all other state activities and "tax morality" which describes the readiness of individual to leave their official occupations or engage after hours in underground economic activities. For indicator variables, researchers do include monetary indicators, labour market indicators, and

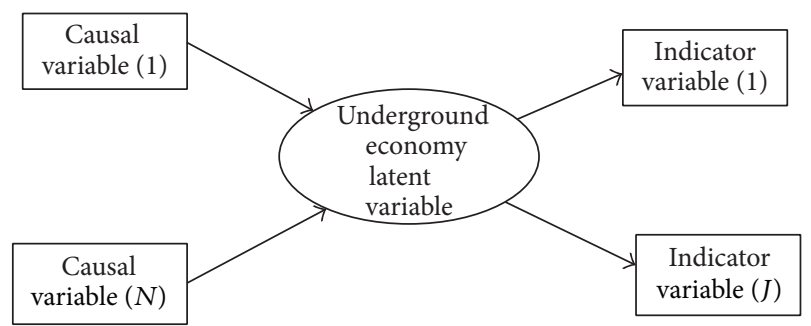

Figure 1: Development of the underground economy. Source: Schneider and Bajada, 2005 [3].

production (input) market indicators (movement of input from official to underground activities).

In recent times the method that has received a relatively wide acceptance in the literature is the monetary approach to measure the underground economy, probably due to its presumed simplicity [61]. Schneider and Bajada [3] suggest that because those who work underground make every attempt to remain unobserved from the authorities by explicitly requesting cash for their services, "monetary approaches" seem to be an efficient way to uncover the trail of these participants. The monetary modelling approach tries to identify the extra currency that may be attributed to the factors which may explain the size of the underground economy. Cagan [62] has been credited as one of the pioneers or proponents of this method. Since Cagan's [62] paper on the measurement of the underground economy, by calculating the correlation between currency demand and the tax pressures (as one cause of the underground economy) for the United States over the period 1919 to 1955, the method has gone through a number of modifications (see [19, 63-65]).

In practice, the method uses econometric tools to estimate a currency demand equation. Once the amount of currency used to make underground transactions is estimated, it could be multiplied by the income-velocity of money to get a measure of the size of the underground economy (see $[19,61,64,66])$. Tanzi's $[63,65]$ study of the underground economy for the United States for the period 1929 to 1980 assumes that an increase in the size of the underground economy will show up as an increase in the demand for currency. Equation (1) presents the basic regression equation for the currency demand as proposed by Tanzi [65]:

$$
\begin{aligned}
\ln \left(\frac{C}{M_{2}}\right)_{t}= & \beta_{0}+\beta_{1} \ln (1+T W)_{t}+\beta_{2} \ln \left(\frac{W S}{Y}\right)_{t} \\
& +\beta_{3} \ln (R)_{t}+\beta_{4} \ln \left(\frac{Y}{N}\right)_{t}+u_{t}
\end{aligned}
$$

with $\beta_{1}>0, \beta_{2}>0, \beta_{3}>0$, and $\beta_{4}>0$, where $\ln$ denotes natural logarithms, $C / M_{2}$ is the ratio of currency in circulation to money supply $M_{2}, T W$ is a weighted average tax rate, $W S / Y$ is a proportion of wages and salaries in national income, $R$ weighted average rate of return on deposits, and $Y / N$ is the per capita income. Once (1) is fitted, any excess increase in currency or the amount unexplained by the conventional, or normal factors is attributed to the factors influencing the size of the underground economy such as the 
rising tax burden. From Tanzi [65] the size and development of the underground economy are calculated by comparing the difference between the development of currency when the direct and indirect tax burden (or other underground economy factors) are held at their lowest level and the development of currency with the current (much higher) burden of tax (or other underground economy factors). This currency demand approach by Tanzi [65] has in itself seen a lot of modification ever since by a number of authors in the field (see $[4,5,14,67-71]$ ). Such modified version of the currency demand approach is adopted in this study.

Despite the wide spread consensus on the use of the currency demand model in measuring the size of the underground economy, there have also been some criticisms of this approach. The assumption of the same velocity of money for both official and underground economies has been criticized. Critics argue that, for even the official economy, there is high uncertainty about the velocity of money, and the velocity of money in the underground is even more difficult to estimate (see $[68,71,72]$ ). However, some currency demand approaches recently proposed have been successful in avoiding the velocity of money circulation approximation. One of such enhanced currency demand models, specifically the one by Giles $[4,5]$, is adopted for this study.

\section{Estimation Methodology and Data}

The model estimation is based on the currency demand methodology of Giles $[4,5]$ which in itself is a modified version of a prior model by Bhattacharyya [73]. Giles [4, 5] implicitly allows for different velocities of circulation in the "underground" and "measured" economy and also avoids a functional approximation which is features of the earlier work by Bhattacharyya [73]. One assumption about the model is that, at any given point in time, the total currency in circulation is the sum of the demand for currency in the measured economy and the demand for currency by the underground economy.

Thus,

$$
M_{t}=M_{m t}+M_{u t} .
$$

Following Baumol and Tobin, the currency demand for the economy is given by

$$
\begin{aligned}
M_{m t} & =\alpha_{0}\left(Y_{m t}\right)^{\alpha_{1}}\left(R_{t}\right)^{\alpha_{2}}\left(P_{t}\right)^{\alpha_{3}}, \\
M_{u t} & =\left(Y_{u t}\right)^{\alpha_{4}},
\end{aligned}
$$

where $Y_{m t}$ and $Y_{u t}$ are "measured" and "underground" real output and income, respectively, $R_{t}$ denotes short-term interest rate and $P_{t}$ is the price level. The total currency in circulation can therefore be obtained by combining (3) and (4) to yield (5):

$$
M_{t}=\alpha_{0}\left(Y_{m t}\right)^{\alpha_{1}}\left(Y_{u t}\right)^{\alpha_{2}}\left(R_{t}\right)^{\alpha_{3}}\left(P_{t}\right)^{\alpha_{4}} .
$$

The unobserved ratio of "underground" to "measured" output is taken to be a function of variables such as the rate of growth in measured output: the inflation rate, the change in inflation rate, and the ratio of tax revenue to GDP (RASTP). The inflation rate is included to serve incentive for tax payer to engage in unreported activities. Thus, a higher cost of living compels people to engage in underground activities. Giles $[4,5]$ indicated that the rational for including the change in the rate of inflation variable in (6) is because such variability adds to uncertainty and strengthens the incentive to enter the underground economy as means of risk or cost reduction. The ratio of "underground" to "measured" output is given by

$$
\begin{aligned}
\frac{Y_{u t}}{Y_{m t}}= & \beta_{1}+\beta_{2} \operatorname{RAST} P_{t}+\beta_{3} \Delta \log Y_{m t} \\
& +\beta_{4} \Delta \log P_{t}+\beta_{5} \Delta\left(\Delta \log P_{t}\right) .
\end{aligned}
$$

Solving (6) for $Y_{u t}$, substituting in (5), taking the (natural) logarithms, adding a dummy variable to capture the effect of the introduction of value added tax (VAT), and adding an error term yield an estimable total currency demand equation (7). Note that lower case symbols denote natural logarithms of the variables:

$$
\begin{gathered}
m_{t}=\alpha_{0}+\left(\alpha_{1}+\alpha_{2}\right) \\
+\alpha_{2} \log \left[\beta_{1}+\beta_{2} \operatorname{RASTP}_{t}+\beta_{3} \Delta \log Y_{m t}\right. \\
\left.\quad+\beta_{4} \Delta \log P_{t}+\beta_{5} \Delta\left(\Delta \log P_{t}\right)\right] \\
+\alpha_{3} r_{t}+\alpha_{4} p_{t}+\gamma \operatorname{DVAT}_{t}+\epsilon_{t} .
\end{gathered}
$$

We estimate the nonlinear currency demand equation (7) to obtain values for the parameter estimates. The $\beta$ 's are then used in (6) to obtain the "underground" to "measured" output ratio for each point in the sample. The estimated value for $\beta_{1}$ represents the long-run average ratio of "underground" to "measured" output.

Annual time series data covering the period 1983-2003 are used to study the underground economy in Ghana. The choice of the length of the period of the study depends solely on data availability. Data on money supply $\left(M_{2}\right)$, general price level (CPI), and the short-term interest rate are obtained from the Bank of Ghana, the Institute of Statistical Social, and Economic Research (ISSER) data files. Real GDP data and ratio of tax revenue to GDP data were obtained from the World Bank data files (WDI).

\section{Empirical Results}

The first subsection presents the result for the nonlinear estimated currency demand equation for Ghana, which recognizes the role of both the "measured" as well as the "underground" economies in influencing total demand for money in the economy. The coefficient estimates from the estimated currency demand model are then implored in computing the ratio of "hidden" to "measured" output which is of interest to this study. Next, the summary statistics of the hidden economy ratio estimates for the period under consideration is discussed, including its long-run value. Finally, the time profile for the ratio of "hidden" to "measured" output for the period 1983-2003 is presented and described. 
5.1. Currency Demand Model. The currency demand model as presented in (7) regresses total currency demand in the Ghanaian economy on independent variables emanating from both the recorded economy and the hidden economy. Variables included in the currency demand model that influences the ratio of "hidden economy" to "recorded economy" estimate directly includes; the ratio of tax revenue to measured output growth in measured output; inflation rate; and a change in the inflation rate. We use the ratio of tax revenue to GDP (RAST) as a fiscal variable that induces people to involve themselves in hidden economy activities. Some studies use the actual tax rate instead, depending on the availability of data, growth in measured output, inflation rate, and a change in the inflation rate. Overall, the determinants of total currency demand in the Ghanaian economy are the short-term interest rate, price level, measured output, the ratio of tax revenue to measured output, growth in measured output, inflation rate, a change in the inflation rate, and a dummy variable representing the role that VAT introduction has on total currency demand. The ratio of "tax revenue" to "measured output" variable serves as a variable that induces agents to make hidden transaction.

Table 5 presents the estimates for the nonlinear currency demand model estimated in this study. The empirical estimation was carried out using the EVIEWS 6 (2008) package. The table of result also includes the a priori expectations of the independent variables which are included in the model. It should be mentioned that the estimates from the currency demand model as presented in Table 5 are long-run estimates and that attempt to estimate the short-run by including the lagged dependent variable was not successful. But, the issue of short-run dynamics via error correction models and its application to money demand equations has been controversial in the literature [74]. It must be mentioned here that the currency demand model estimates here are reported for the period 1983 to 2003. The choice of this time period for the study as mentioned earlier is purely due to the availability of data, especially the data on the ratio of tax revenue to measured output.

The result shows that approximately 85 percent of the variation in the currency demand model estimated for the period 1983 to 2003 is explained by the independent variables included in the model. This is an indication of the strong overall explanatory power of the model. The results indicate that the estimated currency demand model is highly stable, in that most of the estimated regression coefficients have the indicated signs. All the explanatory variables, with the exception of the coefficient of inflation variable $\beta_{4}$ have the expected signs. However, this is not necessarily a problem as this estimate is not significant even at 10 percent level of significance. But, inflation still plays a role in impacting the total demand for currency via the rate of change in inflation variable. The change in the rate of inflation which adds to uncertainty and strengthens the incentive to enter the hidden economy as means of risk or cost reduction (see $[4,5])$ has its estimated coefficient $\beta_{5}$ to be significant and has the expected sign. Specifically, $\alpha_{2}, \beta_{1}$, and $\beta_{2}$ are all significant at the 0.1 percent level of significance; whilst $\gamma$ the coefficient of the dummy which represents the introduction of VAT (value
TABLE 5: Estimated currency demand model.

\begin{tabular}{lccc}
\hline Variable & A priori expectation & Coefficient & $t$-statistic \\
\hline$\alpha_{0}$ & $+/-$ & 310.680 & 1.305 \\
$\alpha_{1}$ & + & -5.149 & -1.299 \\
$\alpha_{2}$ & + & $47.757^{* * *}$ & 11.661 \\
$\beta_{1}$ & + & $0.397^{* * *}$ & 4.292 \\
$\beta_{2}$ & $+/-$ & $-0.207^{* * *}$ & -5.921 \\
$\beta_{3}$ & $+/-$ & $3.764^{*}$ & 2.143 \\
$\beta_{4}$ & + & -0.010 & -0.142 \\
$\beta_{5}$ & + & 0.092 & 1.379 \\
$\alpha_{3}$ & - & -0.833 & -1.368 \\
$\alpha_{4}$ & + & $1.805^{*}$ & 2.351 \\
$\gamma$ & + & $1.894^{* *}$ & 3.303 \\
\hline
\end{tabular}

Note: ${ }^{*} P<0.05,{ }^{* *} P<0.01$, and ${ }^{* * *} P<0.001$.

$R^{2}=0.85$;

Durbin-Watson statistics $=2.42$,

Breush-Godfrey serial correlation LM test, $F$-stat $=1.605(0.227)$.

Heteroscedasticity white test, $F$-stat $=2.29(0.220)$.

Jarque-Bera statistic $=11.3217(0.326)$.

added tax) is significant at the 1 percent level of significance. The coefficients $\beta_{3}$ and $\alpha_{4}$ are all significant at the 5 percent level of significance.

From the results above, we can say that the total demand for currency in the Ghanaian economy is sensitive to changes in measured output, the long-run average size of the ratio of "hidden" to "recorded" economy, ratio of "tax revenue" to "measured output" (fiscal variable), changes in measured output, price index (CPI), and the dummy variable representing the introduction of VAT. The estimation result which appears in Table 5 above in many respects supports Keynes's General Theory. Thus, the income elasticity as well as the price elasticity of currency demand in the Ghanaian economy, not only is positive as postulated in the Keynes's General theory, but also is highly elastic. Even though the demand for currency in the Ghanaian economy depends negatively on the interest rate, the coefficient is not significant as depicted by its associated $t$-value. Kallon's [75] study on currency demand in Ghana however observed a negative as well as a significant relationship between interest rate and currency demand. It can be observed in this study that the inclusion of the hidden economy in the currency demand model of Ghana makes the interest rate effect less important. This may be due to the huge informal sector in Ghana, whose involvement in the banking sector until recently was limited or simply inaccessible in some instances. It may also be due to the fear of incomes earned underground being traced if saved in the banks and possible prosecution thereafter. The result on interest rate gives impetus to modelling approaches adopted in early works on hidden economy. Specifically, Bhattacharyya [73] modelled the demand for currency in the recorded economy and the hidden economy separately. It was observed in that study that the demand for currency in the recorded economy was influenced by recorded output, interest rate, and the price level. However, the modelling approach did recognize that the demand for currency in the hidden economy is influenced only by the hidden economy 
output and that interest rate and price level do not influence currency demand in the hidden economy.

The estimated coefficient of $\alpha_{2}$ which proxy's the omitted wealth from the hidden economy is significant at the 0.1 percent, indicating the existence of a significant hidden economy in Ghana. As mentioned earlier, the coefficient of the dummy variable representing the introduction of VAT is positive and significant. The implication is that the introduction of VAT increases the total demand for currency in the Ghanaian economy. This is partly due to the inadequate education about VAT and the overpoliticization of the tax reforms, leading to general uncertainty in the system during the early days of VAT's introduction.

In terms of the specification of the currency demand model, the results from Table 5 indicate that the estimated model does not exhibit autocorrelated or heteroscedastic disturbances as shown by the Durbin-Watson Statistics and the White's heteroscedasticity $F$-ratio, respectively. Also, the Jarque-Bera chi-square statistic is not significant even at the 10 percent level, implying normality of the estimated residuals. The result from the unit root test as presented in Table 6 indicates that the variables used in the currency demand model of this study do not exhibit the problem of unit root nonstationarity, since the computed ADF teststatistics for each series are lower than their respective critical values at the $1 \%, 5 \%$, and $10 \%$ significant levels. The results further show that the ADF test statistics outcomes are reliable because the Dublin-Watson statistics are large enough (i.e., in the neighborhood of 2), giving the indication that the variable series have no autocorrelation problem. It must also be said that the probabilities and critical values obtained in the unit root test may not be that accurate due to the small sample size. Thus, testing for cointegration relationships in the model may not be of particular importance.

\subsection{Summary Statistics of Underground Economy Measures.} Coefficient estimates from Table 5 are used with (6) to obtain the ratio of "underground" to "measured" output $\left(Y_{h t} / Y_{m t}\right)$ at each point in the sample. The value of the estimated coefficient $\beta_{1}$ measures the long-run average value of $Y_{h t} / Y_{m t}$ ratio of the Ghanaian economy. Therefore, based on the value of the estimated $\beta_{1}$, we infer that the hidden economy approximates about $40 \%$ of the recorded economy over the long-run. Figure 2 shows the bar chart distribution for the "hidden" to "measured" output ratios over the period of the study.

From the summary statistics, the "underground" to "measured" economy output ratio $\left(Y_{u} / Y_{m}\right)$ for the sample ranges from a low of $25.4 \%$ to a high of $53.6 \%$. The mean $Y_{u} / Y_{m}$ ratio for the sample is $35 \%$. From Figure 1, we observed that the year 1999 recorded the lowest "underground" to "measured" output ratio $\left(Y_{u} / Y_{m}\right)$ and 1985 recorded the highest ratio. The ratios of underground to measured output were particularly high during the middle to the late 1980s. The $Y_{u} / Y_{m}$ ratio averages $43 \%$ in the 1980 s, $34 \%$ in the 1990 s, and approximately $28 \%$ in the 2000 s. Thus, there was a $9 \%$ reduction in the size of $Y_{u} / Y_{m}$ ratio between the 1980s and
TABLE 6: Result of unit root test for currency demand model.

\begin{tabular}{lccc}
\hline Variable & ADF test $t$-statistic & Probability & Durbin-Watson stat \\
\hline LRGDP & -6.2475 & 0.0003 & 2.149 \\
LCPI & -4.2348 & 0.0060 & 1.626 \\
LINTRAT & -2.6552 & 0.0000 & 2.071 \\
LM2 & -3.6258 & 0.0153 & 1.819 \\
\hline
\end{tabular}

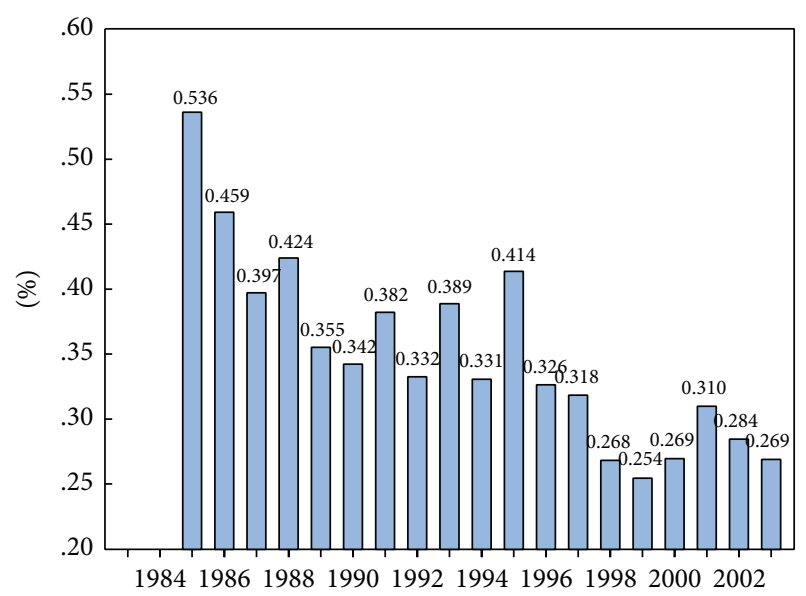

Figure 2: Hidden economy (\% of GDP).

the 1990 s and subsequently $6 \%$ drop in the ratio between the 1990 s and the 2000 s.

5.3. Time Profile of the Underground Economy (\% of GDP). Figure 3 presents the time profile for the estimated ratio of "underground" to "measured" output $\left(Y_{h} / Y_{m}\right)$ over the period of the study. Specifically, the graph shows how the ratio of "underground" to "measured" output varies from the early 1980 s to the early 2000s. It is observed from Figure 2 that the underground to measured output ratios $\left(Y_{h} / Y_{m}\right)$ were relatively high in the 1980 s as compared to the late 1990s. The $Y_{h} / Y_{m}$ ratio of 54 percent in 1985 was particularly high due to inflationary pressures resulting from the removal of budgetary subsidies on consumer goods in 1984. The resulting high prices served as an incentive for people to get involved in hidden economy activities, so that they could reduce their expenditure on goods and services. This effect did normalize over time, leading subsequently to a general decline in the ratio of "underground" to "measured" output after 1985 to 1990 . The reduction in the $Y_{h} / Y_{m}$ ratio, thereafter, can be attributed to the implementation of the monetary and fiscal reforms Ghana embarked on over the period as part of the economic reform program (ERP) of 1983. These reforms were aimed at improving the efficiency of the tax system by widening the tax net without necessarily increasing the tax rate. One of the initiatives in this reform that impacted the underground economy of Ghana considerably was government's renewed commitment in improving tax efficiency through building capacity and increasing morale within the revenue collection agencies, so as to facilitate and monitor taxpayer compliance and prevent noncompliance 


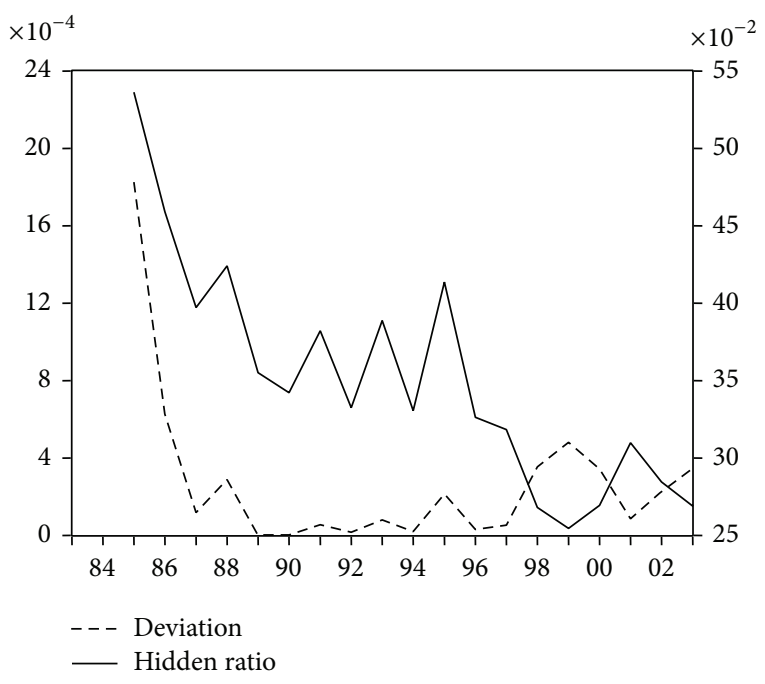

Figure 3: Underground economy (\% of measured GDP).
Political agitations led to the withdrawal of VAT a few months after it became operational. There was this general perception that VAT will increase astronomically the existing prices of goods and services, and as such this led to wide spread demonstration in most of the big cities in Ghana. The lack of political will, coupled with the need to increase education on VAT, led to the withdrawal. The withdrawal of VAT did lead to a reduction in people's involvement in underground economy activities as evident in the data. Thus, the $Y_{h} / Y_{m}$ ratio declined from 41 percent in 1995 to 25 percent in 1999. The underground economy ratio subsequently increased from 25 percent in 1999 to 31 percent in 2001 due to the reintroduction of VAT in 1998. The chow break point test results show the presence of a structural break after 1999. If we compute a chow statistic using 1999 as the breakpoint, we obtain a value of 6.5 which is greater than the critical chi-square value at the 5 percent level of significance and thus provides evidence of a structural break. The rise in underground economy measure between 1999 and 2001 is due to the inadequate education about VAT and the uncertainty surrounding the newly introduced tax system.

[76]. The $Y_{h} / Y_{m}$ ratio declines from approximately 54 percent to 34 percent from 1985 to 1990 due the aforementioned reasons.

The early 1990s saw irregular pattern in the $\left(Y_{h} / Y_{m}\right)$ ratio. For instance, the $Y_{h} / Y_{m}$ ratio rose from 34 percent in 1990 to 38 percent in 1991. It subsequently declined from 38 percent in 1991 to approximately 33 percent in 1992. There was a sharp increase from 33 percent in 1992 to approximately 39 percent 1993. This increase was then followed by a decline to 33 percent in 1994 and a subsequent sharp rise to 41 percent in 1995. The irregular nature of the underground economy ratio in the early 1990s may be attributed to the multiplicity of short-term tax mixed amendments carried out during the period. These amendments inter alia include a reduction of the average personal and income tax and removal of excise duties on a number of products but an increase in the sales tax from an initial level of 10 percent to 20 percent and subsequently to 25 percent around the period (see [76]). The underground economy ratio in the early 1990s was highly responsive to the economic adjustment program, specifically to government's activities aimed at restoring fiscal discipline in the system.

After 1995, the underground to measured output $\left(Y_{h} / Y_{m}\right)$ ratio of the Ghanaian economy did follow a general pattern of decline, so that after 1996 it was oscillating between 31 percent and 25 percent. The general decline in the underground economy ratio after 1996 can be attributed to the introduction of value added tax (VAT) in 1995. The implementation of VAT has increased revenue generation considerably on the long-run. However, the various stages in the introduction of the VAT had corresponding impact on hidden economy activities. For example, VAT was first introduced at a rate of 17.5 percent, 2.5 percent higher than the existing sales tax rate which it was meant to replace. The high initial VAT rate did increase the incentive for people to involve themselves in underground economy activities, as reflected by the high $Y_{h} / Y_{m}$ ratio of 41 percent in 1995.

\section{Conclusion}

The application of the currency demand approach to the Ghanaian economy has helped to explain the determinants of total currency demand in Ghana when we recognize the presence of an underground economy and also helped in measuring the size of the underground economy in Ghana. To the best of our knowledge this study is probably one of the first attempts to measure the underground economy in Ghana using a currency demand approach. Due to the complexity involved in capturing every facet of the underground economy, coupled with the lapses in the existing approaches used in measuring the underground economy, it is fair to say that the estimates may be lower bound estimates.

The result from the currency demand model shows that the inclusion of the underground economy component to the total currency demand equation makes interest rate statistically insignificant in the total currency demand model, despite the fact that prior studies on Ghana which do not consider the presence of an underground economy found interest rate a significant determinant of total currency demand. This study found that underground economy averages approximately 35\% of GDP over the period 1983-2003, ranging from a high of $54 \%$ in 1985 to a low of $25 \%$ in 1999. The estimated long-run average size of the underground economy to GDP for Ghana over the period is $40 \%$ (of GDP).

The results obtained in this study may have important implications for both monetary and fiscal policy redesign. Causal relationships between underground output/income and other macroeconomic variables may be important for policy making and further studies could explore these relationships. The estimates for the size of the underground economy could be improved by including labor market factors (wage rate), proxy for the burden of regulation, and some variables to capture the burden of direct and indirect taxation. It will also be of interest to explore the underground 
economy in Ghana by finding out the demography of people involved and what sectors are the underground activities predominant. Consistent with bridging the tax gap (see [77] for a review of the literature), it will also be of importance to understand and capture the behavioral responses of taxpayers adequately in Ghana across the business cycle and across different enforcement policies. Experimental methods could be used to explore these behavioral responses in order to aid the design of strong tax enforcement institutions.

\section{Conflict of Interests}

The authors declare that there is no conflict of interests regarding the publication of this paper.

\section{References}

[1] World Bank, "Ghana: key development statistics," 2007.

[2] E. Aryeetey, J. M. Harrigan, and Nissanke., Economic Reforms in Ghana, The Miracle and The Mirage, James Currey and Woeli Publishers, Oxford, UK, 2000.

[3] F. Schneider and C. Bajada, "An international comparison of underground activity," in in Size, Causes, and Consequences of the Underground Economy: An Internal, C. Bajada, F. Schneider, and C. Bajada, Eds., pp. 73-106, Aldershot, UK, 2005.

[4] D. E. A. Giles, "Measuring the hidden economy: implications for econometric modelling," The Economic Journal, vol. 109, no. 456, pp. 370-380, 1999.

[5] D. E. A. Giles, Modeling the Hidden Economy in the Tax-Gap in New Zealand, Working Paper, University of Victoria, Victoria, Canada, 1999.

[6] H. Ahumada, F. Alvaredo, and A. Canavese, "The monetary method and the size of the shadow economy: a critical assessment," Review of Income and Wealth, vol. 53, no. 2, pp. 363-371, 2007.

[7] R. Hill, "The underground economy in Canada: boom or bust?" The Canadian Tax Journal, vol. 50, no. 5, pp. 1641-1654, 2002.

[8] P. Lyssiotou, P. Pashardes, and T. Stengos, "Estimates of the black economy based on consumer demand approaches," The Economic Journal, vol. 114, no. 497, pp. 622-640, 2004.

[9] V. Tanzi and L. Schuknecht, "Reconsidering the fiscal role of government: the international perspective," American Economic Review, vol. 87, no. 2, pp. 164-168, 1997.

[10] C. Bajada and F. Schneider, "The size and development of the shadow economies in the Asia-Pacific," Discussion Paper, Department of Economics, University of Linz, Linz, Austria, 2003.

[11] B. Dallago, The Irregular Economy: The "underground economy" and the "black labor market", Publishing Company, Dartmouth, UK, 1990.

[12] M. S. D. Bagachwa and A. Naho, "Estimating the second economy in Tanzania," World Development, vol. 23, no. 8, pp. 1387-1399, 1995.

[13] B. Belev, The Informal Economy in the EU Accession Countries: Size, Scope, Trends and Challenges to the Process of EU Enlargement, Center for Study of Democracy, Sofia, Bulgaria, 2003.

[14] F. Schneider, "Estimating the size of the Danish shadow economy using the currency demand approach: an attempt," The Scandinavian Journal of Economics, vol. 88, no. 4, pp. 643-668, 1986.
[15] P. Smith, "Assessing the size of the underground economy: the Canadian statistical perspectives," Canadian Economic Observer, Catalogue No. 11-010, 3.16-33, 1994.

[16] F. Schneider, "Shadow economies and corruption all over the world: what do we really know?” IZA Discussion Papers 2315, Institute for the Study of Labor (IZA), 2006.

[17] D. L. Lindauer, "Parallel, fragmented, or black? Defining market structure in developing economies," World Development, vol. 17, no. 12, pp. 1871-1880, 1989.

[18] D. L. Bevan, P. Collier, and J. W. Gunning, "Black markets: illegality, information, and rents," World Development, vol. 17, no. 12, pp. 1955-1963, 1989.

[19] P. M. Gutmann, “Subterranean economy," Financial Analysis Journal, vol. 34, no. 6, pp. 26-27, 1977.

[20] J. Yin and Z. Jiangsu, "Econometric model of underground economy scale estimation," International Journal of Nonlinear Science, vol. 7, no. 1, pp. 125-128, 2009.

[21] F. Ogunc and G. Yilmaz, "Estimating the Underground Economy in Turkey," The Central Bank of the Republic of Turkey Research Department Discussion Paper, 2000.

[22] T. R. Tyler, R. J. Boeckmann, H. J. Smith, and Y. J. Huo, Social Justice in a Diverse Society, Westview Press, Boulder, Colo, USA, 1997.

[23] G. S. Becker, "Crime and punishment: an economic approach," Journal of Political Economy, vol. 76, pp. 169-217, 1968.

[24] J. Alm, G. H. McClelland, and W. D. Schulze, "Why do people pay taxes?" Journal of Public Economics, vol. 48, no. 1, pp. 21-38, 1992.

[25] J. Hindriks, M. Keen, and A. Muthoo, "Corruption, extortion and evasion," Journal of Public Economics, vol. 74, no. 3, pp. 395430, 1999.

[26] A. Dreher, C. Kotsogiannis, and S. McCorriston, "How do institutions affect corruption and the shadow economy?" International Tax and Public Finance, vol. 16, no. 6, pp. 773-796, 2009.

[27] S. Johnson, D. Kaufmann, and A. Shleifer, "The unofficial economy in transition," Brookings Papers on Economic Activity, no. 2, pp. 159-239, 1997.

[28] S. Rose-Ackerman, Corruption and Development, The World Bank, Washington, DC, USA, 1997.

[29] J. Choi and M. Thum, "Corruption and the shadow economy," International Economic Review, vol. 46, no. 3, pp. 817-836, 2005.

[30] E. Friedman, S. Johnson, D. Kaufmann, and P. Zoido-Lobatón, "Dodging the grabbing hand: the determinants of unofficial activity in 69 countries," Journal of Public Economics, vol. 76, no. 3, pp. 459-493, 2000.

[31] F. Schneider and D. Enste, The Shadow Economy: Theoretical Approaches, Empirical Studies and Political Implications, Cambridge University Press, Cambridge, UK, 2002.

[32] M. Carter, "Issues in the hidden economy-a survey," Economic Record, vol. 60, no. 3, pp. 209-221, 1984.

[33] D. B. Perry, "Fiscal figures: international tax comparisons," Canadian Tax Journal, vol. 28, no. 1, pp. 89-93, 1980.

[34] B. J. Shelak, "The impact of the U.S. underground economya note relating to the impact on state finances," Journal of Government Information, vol. 24, no. 2, pp. 113-117, 1997.

[35] E. A. Faal, "Currency demand, the underground economy, and tax wvasion: the case of Guyana," International Monetary Fund, IMF Working Papers 03/7, 2003.

[36] R. J. McDonald, "The underground economy and BLS statistics data," Monthly Labour Review, vol. 107, no. 1, pp. 4-16, 1984. 
[37] E. Feige, "A new perspective on macroeconomic phenomena: the theory and measurement of the unobserved sector of the United States economy: causes consequences and implications," in Proceedings of the American Economic Association Meetings, 1980.

[38] N. Jeffrey, "Testimony in underground economy," in U.S. Congress, Committee on Ways and Means Subcommittee on Oversight, 1980, 1979.

[39] I. Hanson, "The underground economy in a high tax country: the case of Sweden," in The Underground Economy in the United States and Abroad, V. Tanzi, Ed., pp. 233-243, Heath, Lexington, DC, USA, 1982.

[40] T. Lemieux, B. Fortin, and P. Frechette, "The effect of taxes on labor supply in the underground economy," American Economic Review, vol. 84, no. 1, pp. 231-254, 1994.

[41] M. Paglin, "The underground economy: new estimates from household income and expenditure surveys," The Yale Law Journal, vol. 103, no. 8, pp. 2239-2257, 1994.

[42] J. B. Rosser Jr., M. V. Rosser, and E. Ahmed, "Income inequality and the informal economy in transition economies," Journal of Comparative Economics, vol. 28, no. 1, pp. 156-171, 2000.

[43] E. Valentini, "Underground economy, evasion and inequality," International Economic Journal, vol. 23, no. 2, pp. 281-290, 2009.

[44] A. Portes, M. Castells, and L. Benton, Eds., The Informal Economy: Studies in Advanced and Less Developed Countries, The Johns Hopkins University Press, Baltimore, Md, USA, 1989.

[45] J. Skolka, "A few facts about the hidden economy seminar-the unofficial economy, consequences and policies in the West and East," in Canadian Public Policy, R. Mirus, R.S. Smith, and V. Karoleff, Eds., vol. 20, pp. 235-252, 1984.

[46] E. Reyneri, "Illegal immigration and the under ground economy," in Proceedings of the Challenges of Immigration and Integration in the European Union and Australia Conference, University of Sydney, February 2003.

[47] J. Prager, Two Cheers for the Underground Economy, Economic Policy Papers, Centre for Applied Economics, New York University, 1983.

[48] P. Harding and R. Jenkins, The Myth of the Hidden Economy, Open University Press, Philadelphia, Pa, USA, 1989.

[49] L. L. Albu, "Estimating the size of underground economy in Romania," Tax Evasion, Underground Economy and Fiscal Policies in Candidate Countries (Case of Romania), GDN Project, Prague, Czech Republic, 2004.

[50] D. E. A. Giles, M. Lindsay, and M. Tedds, "Taxes and the Canadian underground economy," Canadian Tax Paper 106, Canadian Tax Foundation, Toronto, Canada, 2002.

[51] F. Schneider, "The size and development of the shadow economies of 22 transition and 21 OECD countries," IZA Discussion Paper 514, Institute for the Study of Labor (IZA), Bonn, Germany, 2002.

[52] I. Hansson, The Underground Economy in Sweden, Cambridge University Press, Cambridge, UK, 1989, edited by E. L. Feige.

[53] C. A. Pissarides and G. Weber, "An expenditure-based estimate of Britain's black economy," Journal of Public Economics, vol. 39, no. 1, pp. 17-32, 1989.

[54] K. G. Matthews, "The GDP residual error and the black economy: a note," Applied Economics, vol. 16, no. 3, pp. 443-448, 1984.

[55] K. Macafee, "Glimpse of the hidden economy in the national accounts," Economic Trends, vol. 316, pp. 81-87, 1980.
[56] D. K. Bhattacharyya, "On the economic rationale of estimating the hidden economy," The Economic Journal, vol. 109, no. 456, pp. 348-359, 1999.

[57] D. Kaufmann, K. Aleksander, and B. Kaminski, "Integrating the unofficial economy into the dynamics of post-socialist economies: a framework of analysis and evidence," in Economic Transition in the Newly Independent States, B. Kaminski, Ed., M.E. Sharpe Press, Armonk, NY, USA, 1996.

[58] M. Lackó, "The hidden economies of Visegrad countries in international comparison: a household electricity approach," in Hungary: Two Wards a Market Economy, L. Halpern and C. Wyplosz, Eds., pp. 128-152, Cambridge University Press, Cambridge, Mass, USA.

[59] B. S. Frey and H. Weck-Hanneman, "The hidden economy as an "unobserved" variable," European Economic Review, vol. 26, no. 1-2, pp. 33-53, 1984.

[60] J. A. Dennis, S. Friedrich, and G. Damayanti, "Me and my shadow: estimating the size of the U.S. hidden economy from time series data," in Dynamic Econometric Modelling: Proceedings of the Third International Symposium in Economic Theory and Econometrics, W. Barnett, E. Berndt, and H. White, Eds., pp. 297-334, Cambridge University Press, New York, NY, USA, 1988.

[61] H. Ahumada, F. Alvaredo, and A. Canavese, "The monetary method to measure the shadow economy: the forgotten problem of the initial conditions," Economics Letters, vol. 101, no. 2, pp. 97-99, 2008.

[62] P. Cagan, "The demand for currency relative to the total money supply," Journal of Political Economy, vol. 66, no. 3, pp. 302-328, 1958.

[63] V. Tanzi, "The underground economy in the United States: estimates and implications," Banca Nazionale del Lavoro Quarterly Review, vol. 135, pp. 427-453, 1980.

[64] V. Tanzi, The Underground Economy in the United States and Abroad, Lexington, Mass, USA, 1982.

[65] V. Tanzi, "The underground economy in the United States: annual estimates, 1930-1980," IMF Staff Papers, vol. 30, pp. 283$305,1983$.

[66] E. Feige, "How big is the irregular economy?" Challenge, vol. 22, no. 1, pp. 5-13, 1979.

[67] M. H. Hussain and Q. Ahmed, "Estimating the black economy through monetary approach: a case of Pakistan," MPRA Paper 8153, University of Munich, Munich, Germany, 2006.

[68] H. Ahumada, F. Alvaredo, and A. Canavese, "The demand for currency approach and the size of the shadow economy: a critical assessment," Discussion Paper, Delta Ecole Normal Superieure, Paris, France, 2004.

[69] M. D. Gadea and J. M. Serrano-Sanz, "The hidden economy in Spain-a monetary estimation, 1964-1998," Empirical Economics, vol. 27, no. 3, pp. 499-527, 2002.

[70] P. Caridi and P. Passerini, "The underground economy, the demand for currency approach and the analysis of discrepancies: some recent European experience," Review of Income and Wealth, vol. 47, no. 2, pp. 239-250, 2001.

[71] J. Klovland, "Tax evasion and the demand for currency in Norway and Sweden: is there a hidden relationship?" Scandinavian Journal of Economics, vol. 86, no. 4, pp. 423-439, 1984.

[72] R. Hill and M. Kabir, "Tax rates, tax mix, and the growth of the underground economy in Canada: what can we infer?" Canadian Tax Journal, vol. 44, no. 6, pp. 1552-1583, 1996. 
[73] D. K. Bhattacharyya, "An econometric method of estimating the hidden economy, United Kingdom (1960-1984): estimates and tests," The Economic Journal, vol. 100, no. 402, pp. 703-717, 1990.

[74] R. L. Thomas, Introductory Econometrics: Theory and Applications, Longman, New York, NY, USA, 1998.

[75] K. M. Kallon, "An econometric analysis of money demand in Ghana," The Journal of Developing Areas, vol. 26, no. 4, pp. 475488, 1992.

[76] R. D. Osei and P. Quartey, "Tax reforms in Ghana (UNUWIDER Research Paper No. 2005/66)," UNU-WIDER, Helsinki, Finland, 2005.

[77] N. Gemmell and J. Hasseldine, "The tax gap: a methodological Review," Working Paper 09/2012, Victorial Univeristy Wellington School of Business Working, 2012. 

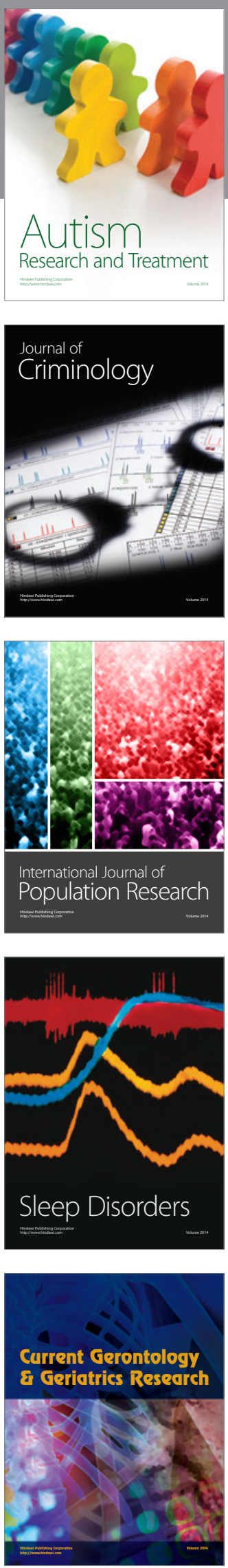
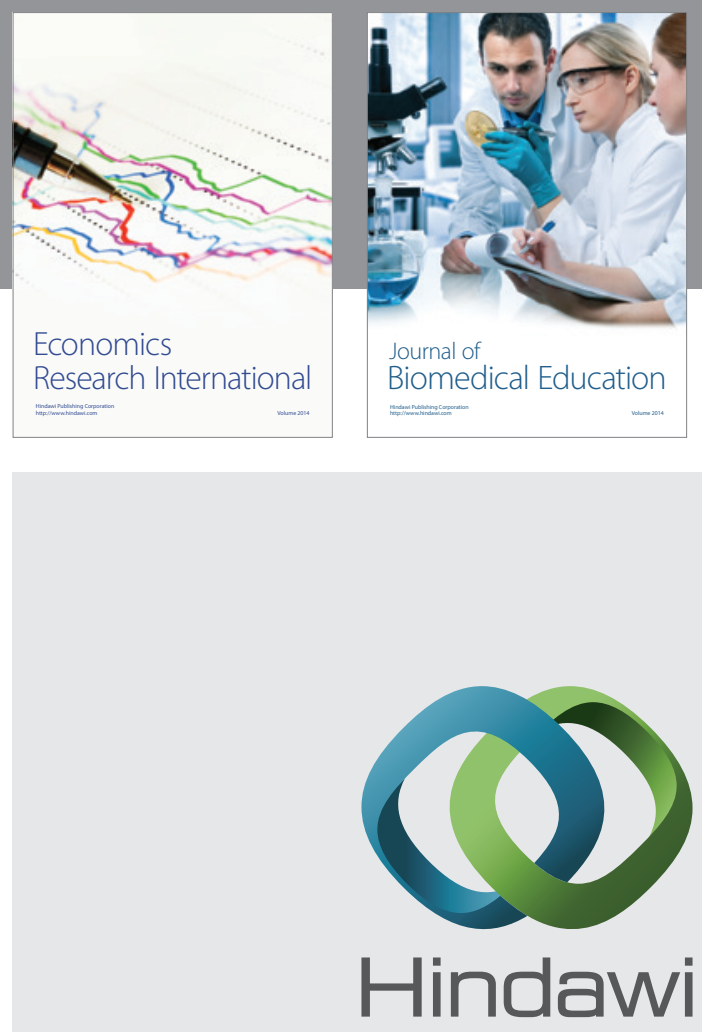

Submit your manuscripts at

http://www.hindawi.com
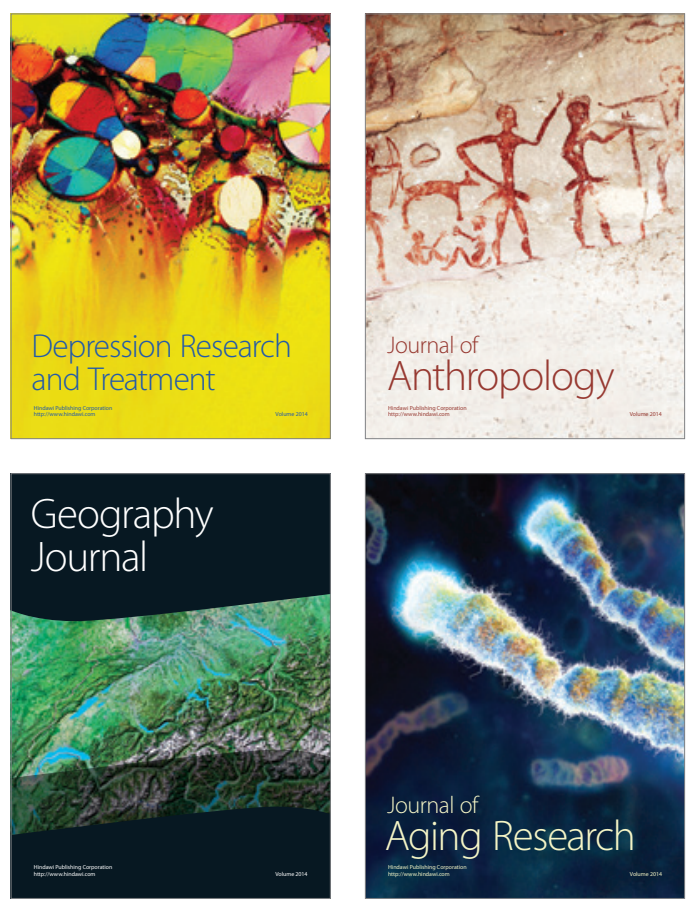
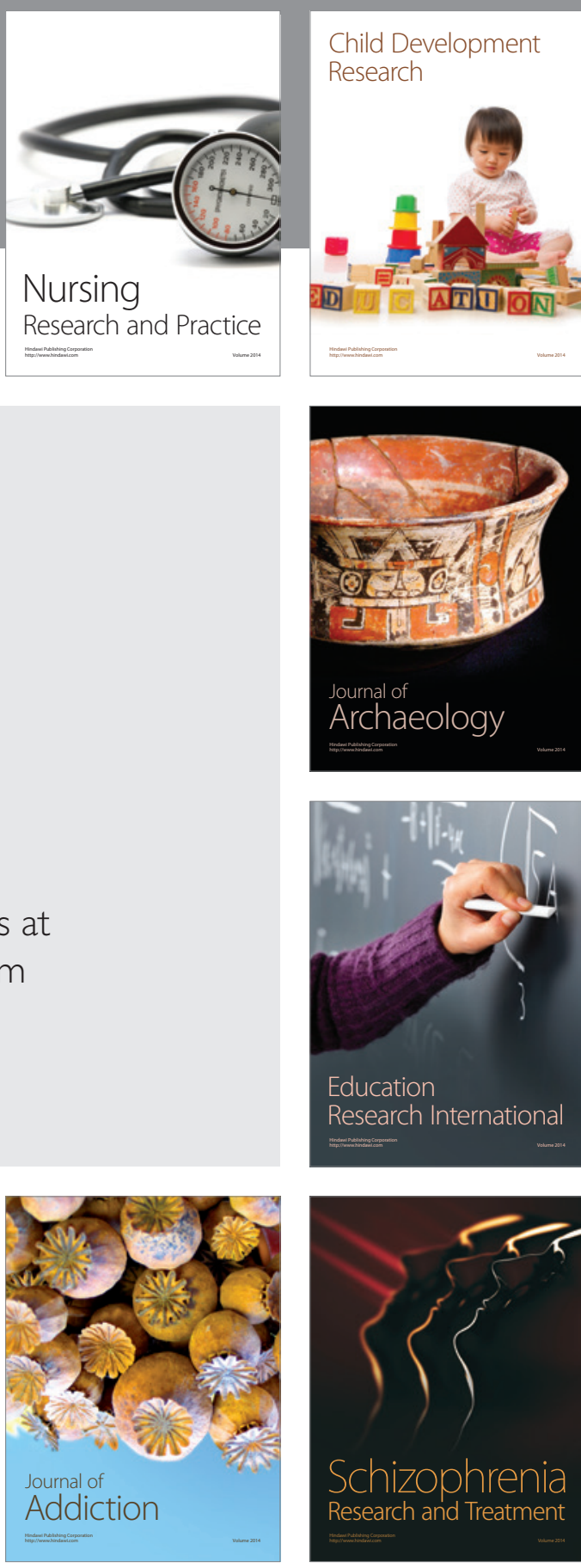

(D)
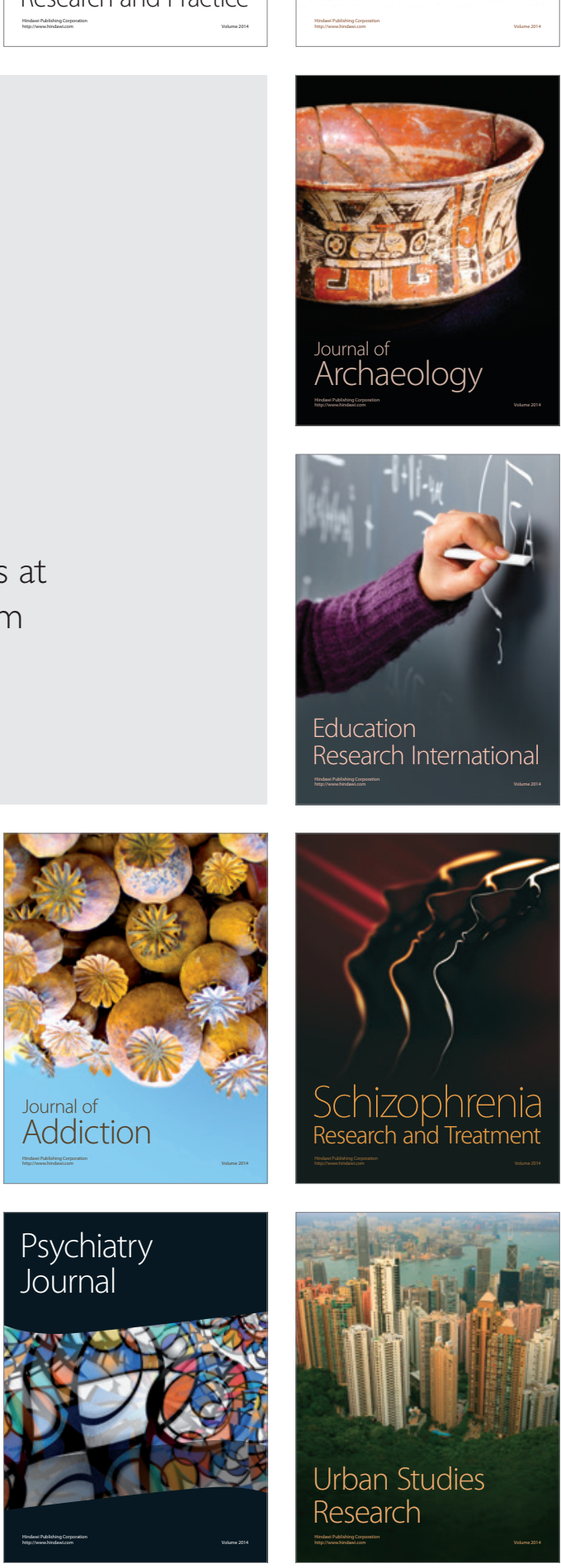